\title{
Structure of the HIV-1 frameshift site RNA bound to a small molecule inhibitor of viral replication
}

\author{
Ryan J. Marcheschi ${ }^{1}$, Marco Tonelli ${ }^{1}$, Arvind Kumar ${ }^{2}$, and Samuel E. Butcher ${ }^{1,{ }^{*}}$ \\ ${ }^{1}$ Department of Biochemistry, University of Wisconsin-Madison \\ 2 Department of Chemistry, Georgia State University
}

\section{Abstract}

Programmed -1 translational frameshifting is an essential event in the replication cycle of HIV. Frameshifting is required for expression of the viral Pol proteins, and drug-like molecules that target this process may inhibit HIV replication. A small molecule stimulator of HIV-1 frameshifting and inhibitor of viral replication, DB213 (RG501), was previously discovered from a high throughput screen. However, the mechanistic basis for this compound's effects was unknown, and to date no structural information exists for small molecule effectors of frameshifting. Here, we investigate the binding of DB213 to the frameshift site RNA and have determined the structure of this complex by NMR. Binding of DB213 stabilizes the RNA and increases its melting temperature by $10^{\circ} \mathrm{C}$. The ligand binds to a primary site on the RNA stemloop, although non-specific interactions are also detected. The compound binds in the major groove and spans a distance of 9 base pairs. DB213 hydrogen bonds to phosphate groups on opposite sides of the major groove and alters the conformation of a conserved GGA bulge in the RNA. This study may provide a starting point for structure-based optimization of compounds targeting the HIV-1 frameshift site RNA.

\section{Introduction}

More than a quarter century after its initial identification, human immunodeficiency virus (HIV), the primary cause of AIDS (1), continues to be a major health concern. Current estimates indicate 33 million people infected worldwide with HIV, with more than 25 million having died due to complications arising from AIDS (2). Recent data show little slowing of this trend, with 2.7 million people becoming newly infected with HIV and 2 million people dying from AIDS in 2007 (2). Great advances have been made, however, including the production of many drugs targeting the protease, reverse transcriptase, and integrase functions of the enzymatic proteins produced by HIV-1 (3-6). These drugs, when taken together in the form of highly active anti-retroviral therapy (HAART), have proven successful in delaying mortality while maintaining the infection at very low viral loads (710). However, the ability of HIV to develop resistance to these drugs is an ongoing and increasingly concerning problem, particularly due to the prevalence of multi-drug resistant mutants (11-15).

\footnotetext{
“Corresponding author: 433 Babcock Dr. Madison, WI 53706, utcher@biochem.wisc.edu.

Data Bank accession codes

Coordinates for the DB213-RNA complex have been deposited into the RCSB Protein Data Bank (accession code 2L94). NMR chemical shift assignments and 2D NOESY time domain data have been deposited into BioMagResBank.

Associated Content

Supporting Information. This material is available free of charge via the Internet at http://pubs.acs.org.
} 
In attempt to address this problem, recent research has focused on the -1 translational frameshift required by HIV during its replication cycle (16-21). The frameshift event is programmed by two cis-acting RNA elements between the gag and pol genes: a sevennucleotide slippery sequence (UUUUUUA), and a highly conserved stem-loop structure immediately downstream $(22,23)$. This frameshift site (FS) stem-loop structure has been shown to induce ribosomal pausing, which is required for frameshifting, and its stability has been correlated with the efficiency of ribosomal frameshifting $(24,25)$.

As a result of the -1 translational frameshift, which occurs with an efficiency of approximately 5\% $(22,26-31)$, the structural and enzymatic proteins (encoded by the gag and pol genes, respectively) are found in approximately a 20:1 molar ratio. This stoichiometry is required for appropriate packaging of virus particles, and an increase or decrease in the frameshift efficiency has been found to significantly decrease the production of infectious virions $(17,31,32)$.

The requirement of -1 translational frameshifting for viral replication presents a putative drug target that several recent studies have attempted to exploit $(17-21,33)$. The first of these studies was carried out more than a decade ago, where a small molecule identified as part of a screen of 56,000 compounds was found to stimulate frameshifting in HIV-1 (17). This small molecule, 1,4-bis-[ $N$-(3- $N, N$-dimethylpropyl)amidino]benzene tetrahydrochloride, was termed RG501 in the screening study (17) and named DB213 by its original synthesizers (Arvind Kumar and David Boykin, Georgia State University).

Hereafter, we will use the name DB213. Although DB213 was hypothesized to bind to the HIV-1 FS RNA (17), this has never been demonstrated. The binding affinity of DB213 for RNA, and its specificity for the HIV-1 FS RNA, were unknown.

Our lab has previously investigated the thermodynamics and structure of the HIV-1 FS RNA $(19,33-35)$. Here, we investigate DB213 binding to the HIV-1 frameshift site RNA (Figure 1), and determine the NMR structure of the complex. This is the first structure of a complex between the HIV-1 FS RNA and a small molecule that targets frameshifting.

\section{Results and Discussion}

\section{Binding of DB213 to the HIV-1 RNA}

To investigate whether DB213 binds to the HIV-1 FS RNA, we used a stem-loop construct that has been previously characterized by our laboratory $(34,36)$ (Figure 1a). A water-ligand optimized gradient spectroscopy (WaterLOGSY) NMR experiment $(37,38)$ was used to investigate whether DB213 binds directly to the RNA (Figure 2). This is a sensitive binding assay that has been used previously to investigate small molecule binding to this (33) and other RNAs (39). Previously, we found that the WaterLOGSY assay can be used to distinguish between small molecules that bind to the RNA and false positives obtained from a high throughput screen (33). The WaterLOGSY experiment detects binding as a change in sign of the ligand resonances when the small molecule interacts with the more slowly tumbling macromolecule. Indeed, this is what is observed with DB213, indicating that it binds to the HIV-1 FS RNA stem-loop (Figure 2). In contrast, a small molecule that does not bind to the RNA (DSS, 2,2-dimethyl-2-silapentane-5- sulfonic acid), has a peak that does not change sign in the presence of RNA (Figure 2), and serves as a negative control.

\section{DB213 increases HIV-1 RNA stability}

To determine the effect of DB213 addition on the RNA stability, UV-monitored thermal denaturation of the RNA was performed in the presence of varying concentrations of DB213. We found that DB213 stabilized both the lower helix (residues 8-14 and 46-52) and the upper stem-loop (residues 16-41) of the RNA, with a stability increase of approximately 
$10{ }^{\circ} \mathrm{C}$ at a concentration of $100 \mu \mathrm{M}$ (Figure 3); higher concentrations could not be tested due to the absorbance of the compound. An increase in stability of the RNA is still observed in a buffer containing $100 \mathrm{mM} \mathrm{KCl}$ (Figure S1). Since DB213 is a tetracation at pH 7.0, we hypothesized that the increase in stability may reflect electrostatic interactions between the ligand and the RNA rather than binding per se. In fact, addition of $100 \mu \mathrm{M}$ spermine (a tetracation that can bind to RNA) into the RNA gave similar results (data not shown). Therefore, the observed stability increase upon DB213 binding is consistent with electrostatic interactions between the ligand and the RNA; however, these data do not address the issue of binding specificity.

\section{NMR investigation of the DB213-RNA complex}

NMR was used to further investigate the interaction of DB213 with the HIV-1 FS RNA. Titrations of DB213 into ${ }^{13} \mathrm{C} /{ }^{15} \mathrm{~N}$-labeled HIV-1 FS RNA showed that a subset of residues experience chemical shift changes upon addition of the ligand up to 1:1 stoichiometry (Figure 4a). These chemical shift changes map to the center of the RNA, including the GGA bulge. The magnitude of the combined chemical shift changes for seven ${ }^{1} \mathrm{H}-{ }^{13} \mathrm{C}$ correlations exhibiting a linear change in chemical shift indicative of two-state binding (U15 C6/H6, G42 C8/H8, G43 C8/H8, A44 C8/H8 and C2/H2, A45 C2/H2 and C8/H8) was plotted against DB213 concentration and fit using the modified Hill equation (40) to obtain an apparent $K_{d}$ of $360 \pm 26 \mu \mathrm{M}$ and a Hill coefficient of $1.8 \pm 0.2$ (Figure 4a). Evidence for non-two-state binding behavior is observed at one site (C16) (Figure 4a). This apparent nontwo-state behavior may reflect a conformational change and/or additional binding events. Non-specific interactions are seen in NMR experiments at higher ligand concentrations. When ligand is in excess of 1:1 stoichiometry, a second set of peaks (corresponding to the lower helix residues 8-14 and 46-52) start to display chemical shift changes and NOEs to the ligand, indicating binding at a second site (data not shown). This is consistent with the Hill coefficient of 1.8 obtained from fitting the NMR data. Additionally, the apparent cooperativity reported by the Hill coefficient could also arise from favorable electrostatic contributions from the ligand. We conclude that DB213 has a preferred binding site on the RNA (apparent $K_{\mathrm{d}}=360 \mu \mathrm{M}$ ), but also displays non-specific interactions. It is likely that these non-specific interactions are a consequence of electrostatic interactions between the DB213 tetracation and the RNA.

2D NOESY experiments were performed with an equimolar ratio of DB213 to RNA (750 $\mu \mathrm{M}$ of each). A total of 42 intermolecular NOEs were observed (Figure $4 \mathrm{~b}$ ). These NOEs are unambiguously intermolecular, since the RNA does not have chemical shifts in the 2-3 ppm range. Although the complex is in fast exchange with respect to the NMR timescale, the intermolecular NOEs report the bound conformation and are simultaneously satisfied by a single bound molecule of DB213 without violation in all low energy structures. We note that due to the rigid nature of the ligand, a second binding site would necessarily result in additional NOEs that could not be satisfied by a single bound orientation of the ligand. The structure of the DB213-RNA complex was determined using HADDOCK 2.0 (41-43) and refined in implicit solvent using AMBER 9 (44). The 10 lowest energy structures are shown (Figure 5).

DB213 is positioned in the major groove of the upper stem-loop (Figure 5a). In the majority of the structures in the ensemble (6 out of 10), the complex is stabilized by two hydrogen bonds between the amino groups of DB213 and the phosphate oxygens of residues 17 and 34 on opposite sides of the helix, across the major groove (Figure 5b). This is in agreement with peaks observed in the complex that are consistent with hydrogen-bonded amino protons on DB213 (Figure S2). Surprisingly, the central benzdiamidine ring does not stack on the RNA bases, but rather is positioned in the major groove orthogonal to the bases and acts as a linker that positions the amino groups towards the phosphate groups. Additionally, most of 
the DB213 ligand, with the exception of the central benzdiamidine ring, is buried in the major groove and in van der Waals contact with the RNA (Figure 5c). A terminal methyl group of DB213 stacks upon the C9-G34 base pair, and the dynamic GGA bulge (36) undergoes a conformational change upon ligand binding by adopting a more compact structure. This is consistent with the observed chemical shift changes upon DB213 binding, since the bulge conformation is altered from that previously observed in the free form of the RNA (36) (Figure S3). It is likely that the conformational change in the bulge structure is transmitted through a change in geometry of the flanking C9-G34 base pair, which is slightly buckled due to accommodation of the ligand (Figure 5c). The more compact bulge structure in turn provides a better stacking interface for the lower helix (Figure S4) and may contribute (along with favorable electrostatic effects) to the observed increase in stability for the lower helix (Figure 3). Remarkably, the observed DB213 ligand binding site spans a distance of 9 base pairs, from the C9-G34 base pair to the C17-G26 base pair.

Based on these observations, we have several hypotheses regarding the binding site selection of DB213 on the HIV FS RNA. As DB213 spans a distance of 9 base-pairs in the major groove, we hypothesize that a 9 bp helix is required for optimal binding. This explains why DB213 is found bound to the $11 \mathrm{bp}$ upper stem-loop of the RNA and not to the $8 \mathrm{bp}$ lower helix. Additionally, the HIV FS RNA is exceptionally stable $\left(\mathrm{Tm}>90^{\circ} \mathrm{C}\right)(36)$, which may facilitate DB213 binding, as helical fraying may adversely affect binding. Finally, the exceptional stability of the upper stem-loop is owed in part to the G-C rich nature of this RNA, and helices rich in G-C pairs have more electronegative major grooves than helices rich in A-U pairs (45). Therefore, the highly electronegative major groove of the upper stem-loop provides an ideal binding site for DB213.

Although we find that DB213 binds to the HIV-1 FS RNA with only modest affinity ( $K_{d}=$ $360 \mu \mathrm{M}$ ), these results are consistent with the in vitro and cell culture results described in the initial identification of DB213 as a frameshifting stimulator (17). These studies showed that concentrations of $500 \mathrm{ug} / \mathrm{ml}(1.5 \mathrm{mM})$ were required for the maximal inhibitory effect upon HIV-1 replication in cell culture. Although a high concentration of DB213 was also found to have cytotoxic effects (17), the therapeutic index $\left(\mathrm{LD}_{50} / \mathrm{ED}_{50}\right)$ for a $50 \%$ decrease in viral replication in cell culture was found to be $>10$, and some FDA approved drugs have narrower therapeutic indices.

The RNA-ligand complex is stabilized by van der Waals contacts in addition to two hydrogen bonds between the amino groups of DB213 and the phosphate backbone of the RNA (Figure 5). These relatively non-specific interactions are consistent with the observed frameshift-stimulating effects of DB213 on several of the frameshift site RNAs previously tested (17). In accordance with these results and our structural data, we hypothesize that DB213 is capable of interacting with any RNA that has a major groove spanning 9 base pairs. Indeed, DB213 binds to a stem-loop from U6 RNA that contains 11 Watson-Crick pairs, as evidenced by WaterLOGSY (data not shown). Therefore, specificity is likely to be a major hurdle for the development of related compounds that target HIV-1 RNA. For example, the human genome is predicted to encode for 9,404 potential RNA folds with helices containing 15 or more base pairs (50). Therefore, the exact mode of action of DB213 in stimulating frameshifting is still unclear, as it could also more generally affect translation by binding to tRNA or rRNA.

DB213 has interesting structural properties for an RNA-binding ligand. The benzamidine groups on the central ring are common substituents of nucleic acid ligands. For example, the fluorescent stain 4',6-diamidino-2-phenylindole (DAPI) is a benzamidine-containing compound that intercalates into DNA, and derivatives of linked benzamidine compounds (diamidines) have been produced that bind DNA selectively (46). Aromatic diamidines are 
potent trypanocides and pentamidine has been used for over 60 years to treat African trypanosomiasis (sleeping sickness) (47). New improved diamidines, such as the arylimidamides, have potent antileishmanial activity (48). Another interesting feature of DB213 are its dimethylated quaternary ammonium cations. A recently identified benzimadazole inhibitor of the HCV IRES also binds RNA through an aromatic group substituted with two alkyl dimethylated quaternary ammonium cations (49). Hence DB213 has molecular features that may be of general importance for a variety of nucleic acid binding ligands.

It may be possible to optimize DB213, or derivatives of it, to increase specificity and affinity for the HIV-1 FS RNA. One way of accomplishing this is through a fragment-based drug discovery approach (51). This approach has been successfully applied to protein targets for many years, but has only recently been applied to RNA (52). The recent push to develop RNA-focused fragment libraries may facilitate this approach (47). In this regard, DB213 or its derivatives may be considered as RNA-focused fragments. For instance, a molecule akin to DB213 might be linked to compounds that bind the conserved ACAA tetraloop on the HIV-1 RNA, such as guanidinoneomycin B (19), or to compounds that target the GGA bulge, such as doxorubicin (33). Linking these molecules together may provide additional affinity and specificity for the HIV-1 RNA, and therefore lead to the development of lead compounds that specifically target HIV-1 frameshifting.

\section{Materials and Methods}

\section{RNA synthesis and purification}

Milligram quantities of RNA suitable for NMR and UV spectroscopy methods were transcribed in vitro using purified His $_{6}$-tagged T7 RNA polymerase, synthetic DNA oligonucleotides (Integrated DNA Technologies, Inc.), and ribonucleotide triphosphates (Sigma-Aldrich) as described previously (53). Briefly, RNA was purified by denaturing $10 \%$ polyacrylamide gel electrophoresis, recovered by diffusion into $0.3 \mathrm{M}$ sodium acetate, precipitated with ethanol, purified by anion exchange chromatography, again precipitated with ethanol, and desalted. The purified RNA was lyophilized, resuspended in an appropriate buffer (10 $\mathrm{mM}$ HEPES or $10 \mathrm{mM} d 11$-Tris), and brought to $\mathrm{pH} 7.0$ by the addition of $1 \mathrm{M} \mathrm{KOH}$.

\section{Synthesis of Bis-[N-(3-dimethylaminopropyl)amidino]benzene tetrahydrochloride (DB213)}

A stirred, cooled mixture of $6.4 \mathrm{~g}$ ( $0.05 \mathrm{~mole})$ of 1,4-dicyanobenzene, $80 \mathrm{ml}$ ethanol and 75 $\mathrm{ml}$ dry chloroform was prepared and dry $\mathrm{HCl}$ gas was passed through it until saturation. The mixture was allowed to stir at room temperature for 3-4 days until the reaction was complete (checked by IR for the disappearance of the C-N band). Upon dilution with dry ether, a white solid appeared. This was filtered, washed with ether and dried in vacuum at 35 ${ }^{\circ} \mathrm{C}$ for $6 \mathrm{~h}$, resulting in a yield of $11.8 \mathrm{~g}$ (80.5\% yield) of bis-imidate ester hydrochloride. This ester was used directly without further purification in the next step. $1.46 \mathrm{~g}(0.05 \mathrm{~mole})$ of the bis-imidate ester hydrochloride was dissolved in $25 \mathrm{ml}$ absolute ethanol, placed under nitrogen, and $1.53 \mathrm{~g}(0.15 \mathrm{~mole}) \mathrm{N}, \mathrm{N}$-dimethylpropylamine was added. The mixture was stirred at room temperature for $12 \mathrm{~h}$, where the volume was reduced to $10 \mathrm{ml}$. After cooling, the white solid which formed was filtered, washed with (1:1) ether:ethanol, washed again with ether and dried under vacuum for $3 \mathrm{~h}$. The white solid was dissolved in $10 \mathrm{ml}$ ethanol, treated with $15 \mathrm{ml}$ saturated ethanolic $\mathrm{HCl}$ and stirred at $60^{\circ} \mathrm{C}$ for $3 \mathrm{~h}$. The solvent was removed and the compound was dried under vacuum at $70^{\circ} \mathrm{C}$ for $24 \mathrm{~h}$, to give $0.86 \mathrm{~g}(33 \%$ yield) of white solid, mp $278-289{ }^{\circ} \mathrm{C}$ dec. ${ }^{1} \mathrm{H}$ NMR (at $60{ }^{\circ} \mathrm{C}$ in $\mathrm{D}_{2} \mathrm{O} / d 6$-DMSO): $\delta, 7.9$ (s, $4 \mathrm{H}), 3.6(\mathrm{t}, J 7.8 \mathrm{~Hz}, 4 \mathrm{H}), 3.28-3.22(\mathrm{~m}, 4 \mathrm{H}), 2.86(\mathrm{~s}, 12 \mathrm{H}), 2.2-2.1(\mathrm{~m}, 4 \mathrm{H}) .{ }^{13} \mathrm{C} \mathrm{NMR}$ (at $60{ }^{\circ} \mathrm{C}$ in $\mathrm{D}_{2} \mathrm{O} / d 6$-DMSO): $\delta, 164.8,134.2,129.9,56.1,44.2,41.3,23.6$. Anal. Calcd. for 
$\mathrm{C}_{18} \mathrm{H}_{32} \mathrm{~N}_{6} \cdot 4(\mathrm{HCl}) \cdot \mathrm{H}_{2} \mathrm{O}: \mathrm{C}, 43.55 \% ; \mathrm{H}, 7.71 \% ; \mathrm{N}, 16.93 \%$. Found: $\mathrm{C}, 43.53 \% ; \mathrm{H}, 7.48 \% ; \mathrm{N}$, $16.72 \%$. Elemental analysis was performed by Atlantic Microlab Inc. (Norcross, GA).

\section{UV Spectroscopy}

Thermal denaturation of the HIV-1 FS RNA was performed in the presence of varying concentrations of DB213 or spermine using a Cary Model 100 Bio UV-visible spectrophotometer equipped with a Peltier heating accessory and temperature probe. All samples contained $10 \mathrm{mM}$ HEPES (pH $7.6-6.4$ over the range of the assay), $20 \mathrm{mM} \mathrm{KCl}$, and $5 \mu \mathrm{M}$ RNA in a volume of $1 \mathrm{~mL}$. Prior to data collection, samples were heated to $\sim 95$ ${ }^{\circ} \mathrm{C}$ and quickly cooled to ensure homogeneous folding. DB213 or spermine were then added and samples were heated from $20^{\circ} \mathrm{C}$ to $95{ }^{\circ} \mathrm{C}$ at a rate of $1{ }^{\circ} \mathrm{C} / \mathrm{min}$, with absorbance data collected at $270 \mathrm{~nm}$ in $0.5^{\circ} \mathrm{C}$ increments. A minimum of three replicates were acquired for each compound concentration. The data were corrected for compound contributions to $\mathrm{UV}_{270}$ absorbance, normalized at $20^{\circ} \mathrm{C}$, derivatized and fit using a nonlinear least-square fit to solve for $T_{m}$ as previously described (54). Data analysis was performed using Prism 4.3 (GraphPad).

\section{NMR Spectroscopy}

All NMR spectra were obtained on Varian Inova (900 MHz) and Bruker Avance DMX (600 and $750 \mathrm{MHz}$ ) spectrometers at the National Magnetic Resonance Facility at Madison (NMRFAM). The spectrometers at NMRFAM were equipped with single $z$-axis gradient proton, carbon, nitrogen cryogenically cooled probes. Exchangeable resonances were assigned by reference to 2D NOESY ( 150 and $400 \mathrm{msec}$ mixing times) spectra of the RNAligand complex collected in $90 \% \mathrm{H}_{2} \mathrm{O} / 10 \%{ }^{2} \mathrm{H}_{2} \mathrm{O}, 10 \mathrm{mM} d 11$-Tris (temperature-corrected $\mathrm{pH} 7.3)$ at $283 \mathrm{~K}$. Water suppression for these experiments was achieved by using a WATERGATE pulse sequence (55). Non-exchangeable resonances were assigned by reference to $2 \mathrm{D}$ NOESY $\left(50,250\right.$, and $400 \mathrm{msec}$ mixing times) and $2 \mathrm{D}^{1} \mathrm{H}-{ }^{1} \mathrm{H}$ TOCSY spectra of the RNA-ligand complex collected in $100 \%{ }^{2} \mathrm{H}_{2} \mathrm{O}, 10 \mathrm{mM} d 11$-Tris (temperaturecorrected $\mathrm{pH}$ 6.6) at $308 \mathrm{~K}$.

Confirmation of ligand binding to RNA was performed in $90 \% \mathrm{H}_{2} \mathrm{O} / 10 \%{ }^{2} \mathrm{H}_{2} \mathrm{O}, 10 \mathrm{mM}$ d11-Tris (temperature-corrected $\mathrm{pH}$ 7.3) at $283 \mathrm{~K}$ using the Water-Ligand Optimized Gradient Spectroscopy experiment (WaterLOGSY) $(37,38)$ in conjunction with acquisition of 1D reference spectra of the RNA-ligand mixture. Water suppression for these experiments was achieved using a WATERGATE water suppression scheme (55). WaterLOGSY spectra were collected as previously described (33). All spectra were referenced to a 2,2-Dimethyl-2-silapentane-5-sulfonic acid (DSS, Sigma) internal control.

The ligand-binding site on the RNA was mapped by monitoring chemical shift perturbations upon titration of ligand into RNA using $2 \mathrm{D}{ }^{1} \mathrm{H}-{ }^{13} \mathrm{C}$ TROSY-HSQC (Figure S5) experiments at $308 \mathrm{~K} .100 \mu \mathrm{M}{ }^{13} \mathrm{C} /{ }^{15} \mathrm{~N}$-labelled HIV-1 FS RNA in $100 \%{ }^{2} \mathrm{H}_{2} \mathrm{O}, 10 \mathrm{mM} d 11$-Tris (pH 6.6) was used for these experiments, and ligand was titrated from a 0:1 to a 64:1 molar ratio of ligand:RNA. Spectral data were normalized to levels equal to 10 times the estimated experimental noise for each experiment.

Changes in chemical shift in the ${ }^{1} \mathrm{H}$ and ${ }^{13} \mathrm{C}$ dimensions were normalized to their respective gyromagnetic ratios and combined $\left(\Delta \delta_{\mathrm{H}, \mathrm{C}}\right)$. Residues most affected by ligand addition were then fit to the equation:

$$
\Delta \delta_{\mathrm{H}, \mathrm{C}}=\frac{\Delta \delta_{\max }}{2 R}\left[\left(R+L+K_{d}\right)-\sqrt{\left(R+L+K_{d}\right)^{2}-4 R L}\right]
$$


where $\Delta \delta_{\max }$ is a scaling parameter representing the response at maximal binding, $R$ is the total concentration of RNA, $L$ is the total concentration of ligand and $K_{d}$ is the apparent dissociation constant. Results for individual residues were normalized to their respective $\Delta \delta_{\max }$ values, combined, and fit to the modified Hill equation (40):

$$
f_{\mathrm{B}}=\frac{\Delta \delta_{\max }}{1+\left(\frac{K_{d}}{L_{\text {free }}}\right)^{n_{\mathrm{H}}}}
$$

where $f_{\mathrm{B}}$ is the fraction of RNA bound by the small molecule (equivalent to $\Delta \delta_{\mathrm{H}, \mathrm{C}}$ above), $n_{\mathrm{H}}$ is the Hill coefficient, $L_{\text {free }}$ is the concentration of free ligand and $\Delta \delta_{\max }$ and $K_{d}$ are as described above. Fitting the chemical shift changes to equation 1 yields a $K_{\mathrm{d}}=399 \pm 55 \mu \mathrm{M}$, whereas fitting to equation 2 yields a $K_{\mathrm{d}}=360 \pm 26 \mu \mathrm{M}$. These $K_{\mathrm{d}}$ values are not statistically different, although a better fit was obtained with the Hill equation and a coefficient $=1.8$.

Dipolar coupling data were acquired at $308 \mathrm{~K}$ using an equimolar mixture of $1.5 \mathrm{mM}$ RNA and DB213 at natural abundance ${ }^{13} \mathrm{C}(1.1 \%)$ using a $2 \mathrm{D}{ }^{1} \mathrm{H}-{ }^{13} \mathrm{C}$ TROSY-HSQC pulse sequence similar to the one discussed above (Figure S5), with the differences discussed in the Supplementary Material. Isotropic coupling data was collected in $100 \%{ }^{2} \mathrm{H}_{2} \mathrm{O}, 10 \mathrm{mM}$ d11-Tris (pH 6.6). After collection, Pf1 filamentous bacteriophage (ASLA Ltd., Riga, Latvia) was added to a final concentration of $15 \mathrm{mg} / \mathrm{mL}$ to induce partial sample alignment and anisotropic dipolar couplings were collected. Residual dipolar couplings (RDCs) were then calculated as the difference between dipolar coupling values for isotropic and partially aligned samples. PALES software (http://spin.niddk.nih.gov/bax/software/PALES) (56) was used to estimate the values for the axial $\left(D_{\mathrm{a}}\right)$ and rhombic $(R)$ components of the alignment tensor from converged, low energy structures calculated using HADDOCK 2.0 (41-43) in the absence and presence of RDCs. After multiple rounds of structure calculations and refinement of the alignment tensor, the optimal $D_{\mathrm{a}}$ and $R$ values were found to be $-34.0 \mathrm{~Hz}$ and 0.207 , respectively.

All data were processed using XwinNMR (Bruker) or NMRPipe(57) software, and assignments were made using Sparky (http://www.cgl.ucsf.edu/home/sparky/).

\section{Structure Calculations}

NOE distance restraints were categorized as strong (2.25-3.75 $)$ ), medium (2.5-4.5 $)$ ), or weak (3.0-7.0 $\AA$ ) based on the integrated peak volumes obtained from 2D NOESY spectra (50, 250, and $400 \mathrm{msec}$ mixing times). Intermolecular NOEs were grouped into two categories: medium (2.0-6.0 $\mathrm{\AA}$ ) and weak (2.5-6.5 $\mathrm{A})$. To account for possible spin diffusion effects, only intermolecular NOEs that could be observed at $250 \mathrm{~ms}$ mixing time were used. Torsion angle restraints (angles: $\alpha, \beta, \gamma, \delta, \varepsilon, \zeta, v_{1}, v_{2}$, and $\chi$ ) for residues 8-14, $16-26,31-41$, and $46-52$ were constrained to A-form values $(58-60)\left( \pm 15^{\circ}\right)$, which were consistent with NOESY and TOCSY data. Additionally, A-form phosphate backbone restraints for these regions were incorporated as previously described (61). Torsion angles for residues in the ACAA tetraloop (residues 27-30) and around the GGA bulge (residues 15 and 42-45) were left unrestrained, with the exception of experimentally validated glycosidic $(\chi)$ and sugar pucker angles $\left(v_{1}, v_{2}\right)$. Residues with strong $\mathrm{H} 1^{\prime}-\mathrm{H} 2^{\prime}$ and $\mathrm{H} 1^{\prime}-\mathrm{H} 3^{\prime}$ cross-peaks (C28) in $2 \mathrm{D}^{1} \mathrm{H}-{ }^{1} \mathrm{H}$ TOCSY (40 msec mixing time) spectra were restrained to the $\mathrm{C} 2{ }^{\prime}$-endo range $\left(v_{1}: 35 \pm 15^{\circ}, v_{2}:-35 \pm 15^{\circ}\right)$, residues without $\mathrm{H} 1^{\prime}-\mathrm{H} 2^{\prime}$ cross-peaks (A27, G41) were restrained to the $\mathrm{C} 3^{\prime}$-endo range $\left(v_{1}:-25 \pm 15^{\circ}, v_{2}: 36 \pm 15^{\circ}\right)$, and residues which displayed an intermediate $\mathrm{H} 1^{\prime}-\mathrm{H} 2^{\prime}$ cross-peak (U15, A29, A30, G42, G43, A44, A45), indicative of an averaging of sugar puckers, were left unrestrained. Glycosidic torsion angles were assigned by reference to the $50 \mathrm{~ms}$ mixing time NOESY spectra. Residues with medium to weak H1'- 
H6/H8 NOEs and strong H2'-H6/H8 NOEs were considered to be in the anti conformation. All helical residues were determined to be in the anti range, and were restrained to $\chi:-158 \pm$ $15^{\circ}$. Residues with an indeterminate sugar pucker were very loosely restrained to the anti range $\chi:-180 \pm 90^{\circ}$, while $\mathrm{C} 28$ has a $\mathrm{C} 2^{\prime}$-endo sugar pucker which in turn influences the range of available chi angles. The $\mathrm{C} 28$ chi angle was restrained to $\chi_{\mathrm{C} 2^{\prime} \text {-endo }}:-125 \pm 30^{\circ}$ as previously described (53). Hydrogen-bond distance restraints were used for all base pairs identified by NOESY experiments. Weak planarity restraints were used to enforce base pairing during initial generation of structures as previously described (53), but these restraints were removed during structure refinement. Due to the fast exchange of the ligand, the symmetry of the unbound state is maintained as evidenced by degenerate chemical shifts. Therefore, partially ambiguous restraints were used for all intermolecular NOEs. To account for possible spin diffusion effects, only intermolecular NOEs that could be observed at $250 \mathrm{~ms}$ mixing time were used.

HADDOCK 2.0 (41-43) was used to combine the previously determined HIV-1 FS RNA structure (36) (PDB 1Z2J) with DB213 using a rigid-body docking procedure. The starting conformation of DB213 was generated using SYBYL 7.3 and energy-minimized. Docked structures were then subjected to $8 \mathrm{psec}$ of restrained molecular dynamics in torsion angle space, 8 psec of slow cooling, and 14.5 psec of restrained molecular dynamics in Cartesian coordinate space. During the final phase of the restrained molecular dynamics refinement, force constants of $85 \mathrm{kcal} \mathrm{mol}^{-1} \AA^{-2}, 200 \mathrm{kcal} \mathrm{mol}^{-1} \mathrm{rad}^{-2}, 100 \mathrm{kcal} \mathrm{mol}^{-1} \mathrm{rad}^{-2}$, and 0.5 $\mathrm{kcal} \mathrm{mol}^{-1} \mathrm{~Hz}^{-2}$ were used for distance, dihedral, planarity and RDC restraints, respectively. Parameter and topology files for DB213 were created using XPLO2D (62-67). Charges for DB213 were assigned by reference to the CHARMM general force field for drug-like molecules (CGenFF) (68) and incorporated into the topology file. Parameter and topology files are included in Supplemental Information.

Docked structures were refined for 50 psec by using a generalized Born implicit solvent model (69) in AMBER 9 (44). In all AMBER calculations, the amber99 force field (70) was used with force constants of $50 \mathrm{kcal} \mathrm{mol}^{-1} \AA^{-2}$ for distance restraints and $200 \mathrm{kcal} \mathrm{mol}^{-1}$ $\mathrm{rad}^{-2}$ for angle restraints. Charges for DB213 were calculated using the generalized AMBER force field (GAFF) (71) in AMBER 9 (44) and used during refinement. All other parameters were as previously described (72). Final structures were accepted based on criteria of lack of NOE violations $>0.5 \AA$, lack of dihedral violations $>5^{\circ}$, and lowest overall energy. These structures were used to back-calculate RDC values using PALES (56), resulting in a Q-value of 0.158 , an $\mathrm{r}^{2}$ value of 0.973 and a r.m.s.d. for observed versus backcalculated RDCs of $4.1 \mathrm{~Hz}$ (Figure S6). Structures were viewed and analyzed using MOLMOL (73) and figures were created using PyMol (http://www.pymol.org). Structural statistics are presented in Table S1.

\section{Supplementary Material}

Refer to Web version on PubMed Central for supplementary material.

\section{Acknowledgments}

We are grateful to Prof. David W. Boykin (Georgia State University) for providing DB213 and Dr. Lawrence Clos II for assistance with structural analysis. We thank Stephen Martin-Tumasz, Dr. Kirk Vander Meulen and other members of the Butcher laboratory for helpful discussions. We also thank Dr. W. Milo Westler and the staff at the National Magnetic Resonance Facility at Madison (NMRFAM) for assistance with NMR data collection. All NMR studies were carried out at NMRFAM (http://www.nmrfam.wisc.edu/) with support from U.S. National Institutes of Health (NIH) [P41RR02301 (Biomedical Technology Program, National Center for Research Resources) and P41GM66326 (National Institute of General Medical Sciences)]. Equipment funding for the facility was provided by the University of Wisconsin, the NIH [P41GM66326, P41RR02301, RR02781, RR08438], the National Science Foundation [DMB-8415048, OIA-9977486, BIR-9214394], and the U.S. Department of Agriculture. This work was 
supported by NIH grant [GM072447 to S.E.B.], NIH Pre-doctoral Training Grant [T32 GM08349 to R.J.M.], and an E.W. Hopkins Predoctoral Fellowship [to R.J.M].

\section{References}

1. Ward, DE. The AmFAR AIDS handbook: the complete guide to understanding HIV and AIDS. W. W. Norton \& Co; New York, NY, USA: 1998.

2. UNAIDS. 2008 Report on the global AIDS epidemic. UNAIDS; Geneva, Switzerland: 2008.

3. Lefebvre E, Schiffer CA. Resilience to resistance of HIV-1 protease inhibitors: profile of darunavir. AIDS Rev. 2008; 10:131-142. [PubMed: 18820715]

4. Schiller DS, Youssef-Bessler M. Etravirine: A second-generation nonnucleoside reverse transcriptase inhibitor (NNRTI) active against NNRTI-resistant strains of HIV. Clin Ther. 2009; 31:692-704. [PubMed: 19446143]

5. Condra JH, Miller MD, Hazuda DJ, Emini EA. Potential new therapies for the treatment of HIV-1 infection. Annu Rev Med. 2002; 53:541-555. [PubMed: 11818489]

6. Hazuda DJ, Felock P, Witmer M, Wolfe A, Stillmock K, Grobler JA, Espeseth A, Gabryelski L, Schleif W, Blau C, Miller MD. Inhibitors of strand transfer that prevent integration and inhibit HIV-1 replication in cells. Science. 2000; 287:646-650. [PubMed: 10649997]

7. Moore RD, Chaisson RE. Natural history of HIV infection in the era of combination antiretroviral therapy. Aids. 1999; 13:1933-1942. [PubMed: 10513653]

8. Palmer S, Maldarelli F, Wiegand A, Bernstein B, Hanna GJ, Brun SC, Kempf DJ, Mellors JW, Coffin JM, King MS. Low-level viremia persists for at least 7 years in patients on suppressive antiretroviral therapy. Proc Natl Acad Sci U S A. 2008; 105:3879-3884. [PubMed: 18332425]

9. Maldarelli F, Palmer S, King MS, Wiegand A, Polis MA, Mican J, Kovacs JA, Davey RT, RockKress D, Dewar R, Liu S, Metcalf JA, Rehm C, Brun SC, Hanna GJ, Kempf DJ, Coffin JM, Mellors JW. ART suppresses plasma HIV-1 RNA to a stable set point predicted by pretherapy viremia. PLoS Pathog. 2007; 3:e46. [PubMed: 17411338]

10. Bartlett JA, DeMasi R, Quinn J, Moxham C, Rousseau F. Overview of the effectiveness of triple combination therapy in antiretroviral-naive HIV-1 infected adults. Aids. 2001; 15:1369-1377. [PubMed: 11504958]

11. Gonsalez CR, Alcalde R, Nishiya A, Barreto CC, Silva FE, de Almeida A, Mendonca M, Ferreira F, Fernandes SS, Casseb J, Duarte AJ. Drug resistance among chronic HIV-1-infected patients naive for use of anti-retroviral therapy in Sao Paulo city. Virus Res. 2007; 129:87-90. [PubMed: 17686543]

12. Condra JH, Schleif WA, Blahy OM, Gabryelski LJ, Graham DJ, Quintero JC, Rhodes A, Robbins HL, Roth E, Shivaprakash M, et al. In vivo emergence of HIV-1 variants resistant to multiple protease inhibitors. Nature. 1995; 374:569-571. [PubMed: 7700387]

13. Palma AC, Araujo F, Duque V, Borges F, Paixao MT, Camacho R. Molecular epidemiology and prevalence of drug resistance-associated mutations in newly diagnosed HIV-1 patients in Portugal. Infect Genet Evol. 2007; 7:391-398. [PubMed: 17360244]

14. Booth CL, Garcia-Diaz AM, Youle MS, Johnson MA, Phillips A, Geretti AM. Prevalence and predictors of antiretroviral drug resistance in newly diagnosed HIV-1 infection. J Antimicrob Chemother. 2007; 59:517-524. [PubMed: 17213262]

15. Clavel F, Hance AJ. HIV drug resistance. N Engl J Med. 2004; 350:1023-1035. [PubMed: 14999114]

16. Dinman JD, Ruiz-Echevarria MJ, Peltz SW. Translating old drugs into new treatments: ribosomal frameshifting as a target for antiviral agents. Trends in Biotechnology. 1998; 16:190-196. [PubMed: 9586242]

17. Hung M, Patel P, Davis S, Green SR. Importance of ribosomal frameshifting for human immunodeficiency virus type 1 particle assembly and replication. J Virol. 1998; 72:4819-4824. [PubMed: 9573247]

18. McNaughton BR, Gareiss PC, Miller BL. Identification of a selective small-molecule ligand for HIV-1 frameshift-inducing stem-loop RNA from an 11,325 member resin bound dynamic combinatorial library. J Am Chem Soc. 2007; 129:11306-11307. [PubMed: 17722919] 
19. Staple DW, Venditti V, Niccolai N, Elson-Schwab L, Tor Y, Butcher SE. Guanidinoneomycin B recognition of an HIV-1 RNA helix. Chembiochem. 2008; 9:93-102. [PubMed: 18058789]

20. Horiya S, Koh CS, Matsufuji S, Harada K. Analysis of the interaction between selected RNAbinding peptides and a target RNA containing a bulge and a GNRA-type tetraloop. Nucleic Acids Symp Ser (Oxf). 2008:209-210.

21. Dulude D, Theberge-Julien G, Brakier-Gingras L, Heveker N. Selection of peptides interfering with a ribosomal frameshift in the human immunodeficiency virus type 1. RNA. 2008; 14:981991. [PubMed: 18367719]

22. Jacks T, Power MD, Masiarz FR, Luciw PA, Barr PJ, Varmus HE. Characterization of ribosomal frameshifting in HIV-1 gag-pol expression. Nature. 1988; 331:280-283. [PubMed: 2447506]

23. Brierley I, Pennell S. Structure and function of the stimulatory RNAs involved in programmed eukaryotic-1 ribosomal frameshifting. Cold Spring Harb Symp Quant Biol. 2001; 66:233-248. [PubMed: 12762025]

24. Telenti A, Martinez R, Munoz M, Bleiber G, Greub G, Sanglard D, Peters S. Analysis of natural variants of the human immunodeficiency virus type 1 gag-pol frameshift stem-loop structure. J Virol. 2002; 76:7868-7873. [PubMed: 12097600]

25. Bidou L, Stahl G, Grima B, Liu H, Cassan M, Rousset JP. In vivo HIV-1 frameshifting efficiency is directly related to the stability of the stem-loop stimulatory signal. RNA. 1997; 3:1153-1158. [PubMed: 9326490]

26. Parkin NT, Chamorro M, Varmus HE. Human immunodeficiency virus type 1 gag-pol frameshifting is dependent on downstream mRNA secondary structure: demonstration by expression in vivo. J Virol. 1992; 66:5147-5151. [PubMed: 1321294]

27. Park J, Morrow CD. Overexpression of the gag-pol precursor from human immunodeficiency virus type 1 proviral genomes results in efficient proteolytic processing in the absence of virion production. J Virol. 1991; 65:5111-5117. [PubMed: 1870215]

28. Kim YG, Maas S, Rich A. Comparative mutational analysis of cis-acting RNA signals for translational frameshifting in HIV-1 and HTLV-2. Nucleic Acids Res. 2001; 29:1125-1131. [PubMed: 11222762]

29. Leger M, Sidani S, Brakier-Gingras L. A reassessment of the response of the bacterial ribosome to the frameshift stimulatory signal of the human immunodeficiency virus type 1. RNA. 2004; 10:1225-1235. [PubMed: 15247429]

30. Dulude D, Baril M, Brakier-Gingras L. Characterization of the frameshift stimulatory signal controlling a programmed -1 ribosomal frameshift in the human immunodeficiency virus type 1 . Nucleic Acids Res. 2002; 30:5094-5102. [PubMed: 12466532]

31. Dulude D, Berchiche YA, Gendron K, Brakier-Gingras L, Heveker N. Decreasing the frameshift efficiency translates into an equivalent reduction of the replication of the human immunodeficiency virus type 1. Virology. 2006; 345:127-136. [PubMed: 16256163]

32. Shehu-Xhilaga M, Crowe SM, Mak J. Maintenance of the Gag/Gag-Pol ratio is important for human immunodeficiency virus type 1 RNA dimerization and viral infectivity. J Virol. 2001; 75:1834-1841. [PubMed: 11160682]

33. Marcheschi RJ, Mouzakis KD, Butcher SE. Selection and Characterization of Small Molecules That Bind the HIV-1 Frameshift Site RNA. ACS Chem Biol. 2009; 4:844-854. [PubMed: 19673541]

34. Staple DW, Butcher SE. Solution structure of the HIV-1 frameshift inducing stem-loop RNA. Nucleic Acids Res. 2003; 31:4326-4331. [PubMed: 12888491]

35. Staple, DW. Structural and Thermodynamic Investigation of the HIV-1 Frameshift Inducing RNA. Department of Biochemistry, University of Wisconsin-Madison; Madison: 2006.

36. Staple DW, Butcher SE. Solution structure and thermodynamic investigation of the HIV-1 frameshift inducing element. J Mol Biol. 2005; 349:1011-1023. [PubMed: 15927637]

37. Dalvit C, Pevarello P, Tato M, Veronesi M, Vulpetti A, Sundstrom M. Identification of compounds with binding affinity to proteins via magnetization transfer from bulk water. J Biomol NMR. 2000; 18:65-68. [PubMed: 11061229] 
38. Dalvit C, Fogliatto G, Stewart A, Veronesi M, Stockman B. WaterLOGSY as a method for primary NMR screening: practical aspects and range of applicability. J Biomol NMR. 2001; 21:349-359. [PubMed: 11824754]

39. Johnson EC, Feher VA, Peng JW, Moore JM, Williamson JR. Application of NMR SHAPES screening to an RNA target. J Am Chem Soc. 2003; 125:15724-15725. [PubMed: 14677945]

40. Bindslev, N. Drug-Acceptor Interactions: modeling theoretical tools to test and evaluate experimental equilibrium effects. Co-Action Publishing; Sweden: 2008.

41. Dominguez C, Boelens R, Bonvin AM. HADDOCK: a protein-protein docking approach based on biochemical or biophysical information. J Am Chem Soc. 2003; 125:1731-1737. [PubMed: 12580598]

42. de Vries SJ, van Dijk AD, Krzeminski M, van Dijk M, Thureau A, Hsu V, Wassenaar T, Bonvin AM. HADDOCK versus HADDOCK: new features and performance of HADDOCK2.0 on the CAPRI targets. Proteins. 2007; 69:726-733. [PubMed: 17803234]

43. van Dijk AD, Bonvin AM. Solvated docking: introducing water into the modelling of biomolecular complexes. Bioinformatics. 2006; 22:2340-2347. [PubMed: 16899489]

44. Case DA, Cheatham TE 3rd, Darden T, Gohlke H, Luo R, Merz KM Jr, Onufriev A, Simmerling C, Wang B, Woods RJ. The Amber biomolecular simulation programs. J Comput Chem. 2005; 26:1668-1688. [PubMed: 16200636]

45. Xu D, Landon T, Greenbaum NL, Fenley MO. The electrostatic characteristics of G.U wobble base pairs. Nucleic Acids Res. 2007; 35:3836-3847. [PubMed: 17526525]

46. Munde M, Kumar A, Nhili R, Depauw S, David-Cordonnier MH, Ismail MA, Stephens CE, Farahat AA, Batista-Parra A, Boykin DW, Wilson WD. DNA minor groove induced dimerization of heterocyclic cations: compound structure, binding affinity, and specificity for a TTAA site. J Mol Biol. 2010; 402:847-864. [PubMed: 20713062]

47. Paine MF, Wang MZ, Generaux CN, Boykin DW, Wilson WD, De Koning HP, Olson CA, Pohlig G, Burri C, Brun R, Murilla GA, Thuita JK, Barrett MP, Tidwell RR. Diamidines for human African trypanosomiasis. Curr Opin Investig Drugs. 2010; 11:876-883.

48. Wang MZ, Zhu XH, Srivastava A, Liu Q, Sweat JM, Pandharkar T, Stephens CE, Riccio E, Parman T, Munde M, Mandal S, Madhubala R, Tidwell RR, Wilson WD, Boykin DW, Hall JE, Kyle DE, Werbovetz KA. Novel Arylimidamides for Treatment of Visceral Leishmaniasis. Antimicrob Agents Ch. 2010; 54:2507-2516.

49. Parsons J, Castaldi MP, Dutta S, Dibrov SM, Wyles DL, Hermann T. Conformational inhibition of the hepatitis C virus internal ribosome entry site RNA. Nat Chem Biol. 2009; 5:823-825. [PubMed: 19767736]

50. Pedersen JS, Bejerano G, Siepel A, Rosenbloom K, Lindblad-Toh K, Lander ES, Kent J, Miller W, Haussler D. Identification and classification of conserved RNA secondary structures in the human genome. PLoS Comput Biol. 2006; 2:e33. [PubMed: 16628248]

51. Hajduk PJ, Greer J. A decade of fragment-based drug design: strategic advances and lessons learned. Nat Rev Drug Discov. 2007; 6:211-219. [PubMed: 17290284]

52. Bodoor K, Boyapati V, Gopu V, Boisdore M, Allam K, Miller J, Treleaven WD, Weldeghiorghis T, Aboul-ela F. Design and implementation of an ribonucleic acid (RNA) directed fragment library. J Med Chem. 2009; 52:3753-3761. [PubMed: 19445516]

53. Marcheschi RJ, Staple DW, Butcher SE. Programmed ribosomal frameshifting in SIV is induced by a highly structured RNA stem-loop. J Mol Biol. 2007; 373:652-663. [PubMed: 17868691]

54. John DM, Weeks KM. van't Hoff enthalpies without baselines. Protein Science. 2000; 9:14161419. [PubMed: 10933511]

55. Piotto M, Saudek V, Sklenar V. Gradient-tailored excitation for single-quantum NMR spectroscopy of aqueous solutions. J Biomol NMR. 1992; 2:661-665. [PubMed: 1490109]

56. Zweckstetter M, Bax A. Prediction of sterically induced alignment in a dilute liquid crystalline phase: aid to protein structure determination by NMR. J Am Chem Soc. 2000; 122:3791-3792.

57. Delaglio F, Grzesiek S, Vuister GW, Zhu G, Pfeifer J, Bax A. NMRPipe: a multidimensional spectral processing system based on UNIX pipes. J Biomol NMR. 1995; 6:277-293. [PubMed: 8520220] 
58. Arnott S, Hukins DW, Dover SD, Fuller W, Hodgson AR. Structures of synthetic polynucleotides in the A-RNA and A'-RNA conformations: x-ray diffraction analyses of the molecular conformations of polyadenylic acid--polyuridylic acid and polyinosinic acid--polycytidylic acid. J Mol Biol. 1973; 81:107-122. [PubMed: 4777303]

59. Chandrasekaran, R.; Arnott, S. Landolt-Bornstein, New Series, Group VII. Saenger, W., editor. Springer; Berlin, Germany: 1989. p. 31-170.

60. Saenger, W. Principles of Nucleic Acids. Springer-Verlag; New York: 1984.

61. Davis JH, Tonelli M, Scott LG, Jaeger L, Williamson JR, Butcher SE. RNA helical packing in solution: NMR structure of a $30 \mathrm{kDa}$ GAAA tetraloop-receptor complex. J Mol Biol. 2005; 351:371-382. [PubMed: 16002091]

62. Kleywegt GJ. Dictionaries for Heteros. CCP4/ESF-EACBM Newsletter on Protein Crystallography. 1995; 31:45-50.

63. Kleywegt GJ. Making the most of your search model. CCP4/ESF-EACBM Newsletter on Protein Crystallography. 1996; 32:32-36.

64. Kleywegt, GJ.; Zou, JY.; Kjeldgaard, M.; Jones, TA. Around O. In: Rossmann, MG.; Arnold, E., editors. International Tables for Crystallography, Vol. F. Crystallography of Biological Macromolecules. Kluwer Academic Publishers; Dordrecht, The Netherlands: 2001. p. 353-356.p. 366-367.

65. Kleywegt GJ. Crystallographic refinement of ligand complexes. Acta Crystallogr D Biol Crystallogr. 2007; 63:94-100. [PubMed: 17164531]

66. Kleywegt GJ, Henrick K, Dodson EJ, van Aalten DM. Pound-wise but penny-foolish: How well do micromolecules fare in macromolecular refinement? Structure. 2003; 11:1051-1059. [PubMed: 12962624]

67. Kleywegt GJ, Jones TA. Model building and refinement practice. Methods Enzymol. 1997; 277:208-230. [PubMed: 18488311]

68. Vanommeslaeghe K, Hatcher E, Acharya C, Kundu S, Zhong S, Shim J, Darian E, Guvench O, Lopes P, Vorobyov I, Mackerell AD Jr. CHARMM general force field: A force field for drug-like molecules compatible with the CHARMM all-atom additive biological force fields. J Comput Chem. 2010; 31:671-690. [PubMed: 19575467]

69. Tsui V, Case DA. Theory and applications of the generalized Born solvation model in macromolecular simulations. Biopolymers. 2000; 56:275-291. [PubMed: 11754341]

70. Cornell WD, Cieplak P, Bayly CI, Gould IR, Merz KM, Ferguson DM, Spellmeyer DC, Fox T, Caldwell JW, Kollman PA. A Second Generation Force Field for the Simulation of Proteins, Nucleic Acids, and Organic Molecules. Journal of the American Chemical Society. 1995; 117:5179-5197.

71. Junmei W, Romain MW, James WC, Peter AK, David AC. Development and testing of a general amber force field. Journal of Computational Chemistry. 2004; 25:1157-1174. [PubMed: 15116359]

72. Venditti V, Clos Ii L, Niccolai N, Butcher SE. Minimum-Energy Path for a U6 RNA Conformational Change Involving Protonation, Base-Pair Rearrangement and Base Flipping. Journal of Molecular Biology. 2009; 391:894-905. [PubMed: 19591840]

73. Koradi R, Billeter M, Wuthrich K. MOLMOL: a program for display and analysis of macromolecular structures. J Mol Graph. 1996; 14:51-55. 29-32. [PubMed: 8744573] 
a

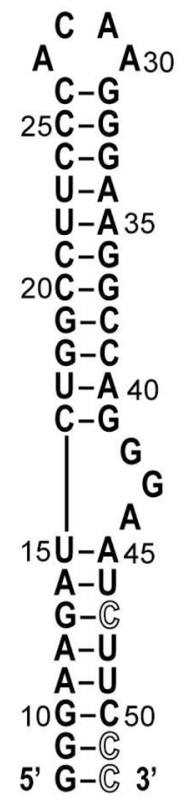

b<smiles>C[NH+](C)CCC[NH+]=C(N)c1ccc(C(N)=[NH+]CCC[NH+](C)C)cc1</smiles>

Figure 1.

Schematic diagrams of the HIV-1 RNA frameshift site stem-loop and DB213. (a) HIV-1 frameshift site RNA stem-loop. Residues in outline indicate where uridines commonly found at positions 47, 51, and 52 were changed to cytidines to stabilize the RNA and improve its folding properties(35). The construct is numbered starting from the first residue of the UUUUUUA slippery sequence (not shown), which is immediately adjacent to the $5^{\prime}$ end of the stem-loop. (b) Structure of DB213 (1,4-bis-[N-(3-N,N-

dimethylpropyl)amidino]benzene tetrahydrochloride), with carbon atoms labeled according to their respective positions relative to the central benzdiamidine. 


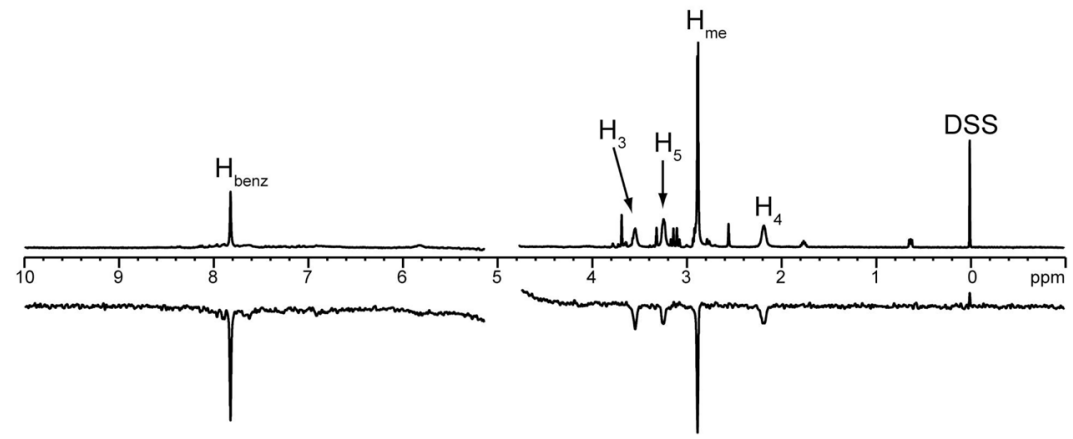

Figure 2.

NMR analysis of HIV-1 FS RNA and DB213. 1D reference experiment (upper spectrum) and WaterLOGSY experiment (lower spectrum). Both experiments were performed on a mixture of DB213 and RNA (10:1 molar ratio). The 0 ppm internal reference standard is indicated (DSS), which also serves as a control small molecule that does not bind RNA. The DSS signal is phased to be positive in both the 1D reference and the WaterLOGSY experiments. Residual water signal ( $\sim 5 \mathrm{ppm})$ has been removed for clarity and DB213 peaks are indicated and numbered, with $\mathrm{H}_{\text {benz }}$ representing ambiguous hydrogens attached to carbons in the benzdiamidine group, $\mathrm{H}_{\text {me }}$ representing ambiguous hydrogens attached to the terminal methyls in the dimethyl ammonium groups, and $\mathrm{H}_{3}, \mathrm{H}_{4}$, and $\mathrm{H}_{5}$ representing ambiguous hydrogens attached to the symmetric carbons labeled as 3, 4, and 5 in Figure 1, respectively. 


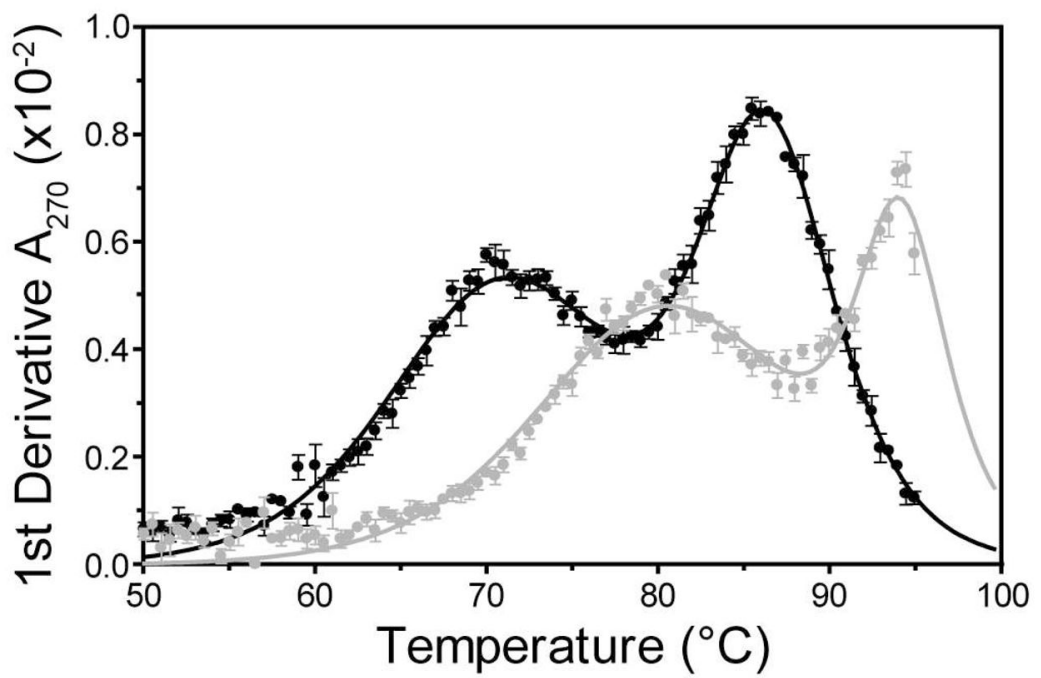

Figure 3.

Effects of DB213 on RNA stability. First derivative plots of UV-monitored thermal denaturation of RNA in the presence of $0 \mu \mathrm{M}$ DB213 (black circles) or $100 \mu \mathrm{M}$ DB213 (gray circles). Data fitting results are indicated by black and gray lines for $0 \mu \mathrm{M}$ and $100 \mu \mathrm{M}$ DB213, respectively. At $0 \mu \mathrm{M}$ DB213, the transition melting temperatures for the lower helix $\left(T m_{1}\right)$ and upper stem-loop $\left(T m_{2}\right)$ are $70.9 \pm 0.3{ }^{\circ} \mathrm{C}$ and $86.3 \pm 0.3{ }^{\circ} \mathrm{C}$, respectively, while at $100 \mu \mathrm{M}$ DB213 these temperatures are $80.3 \pm 0.3{ }^{\circ} \mathrm{C}$ and $94.2 \pm 0.3{ }^{\circ} \mathrm{C}$, respectively. 
a
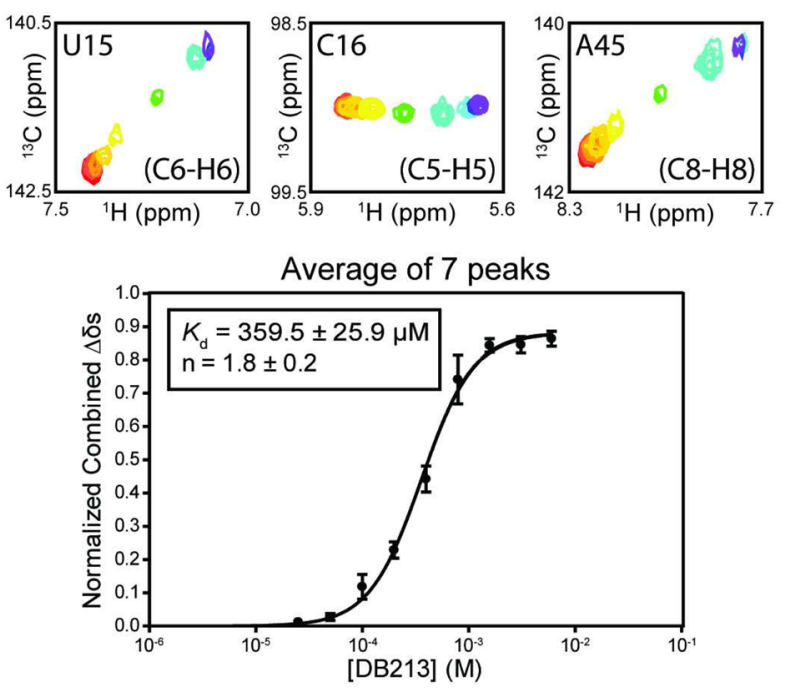

b

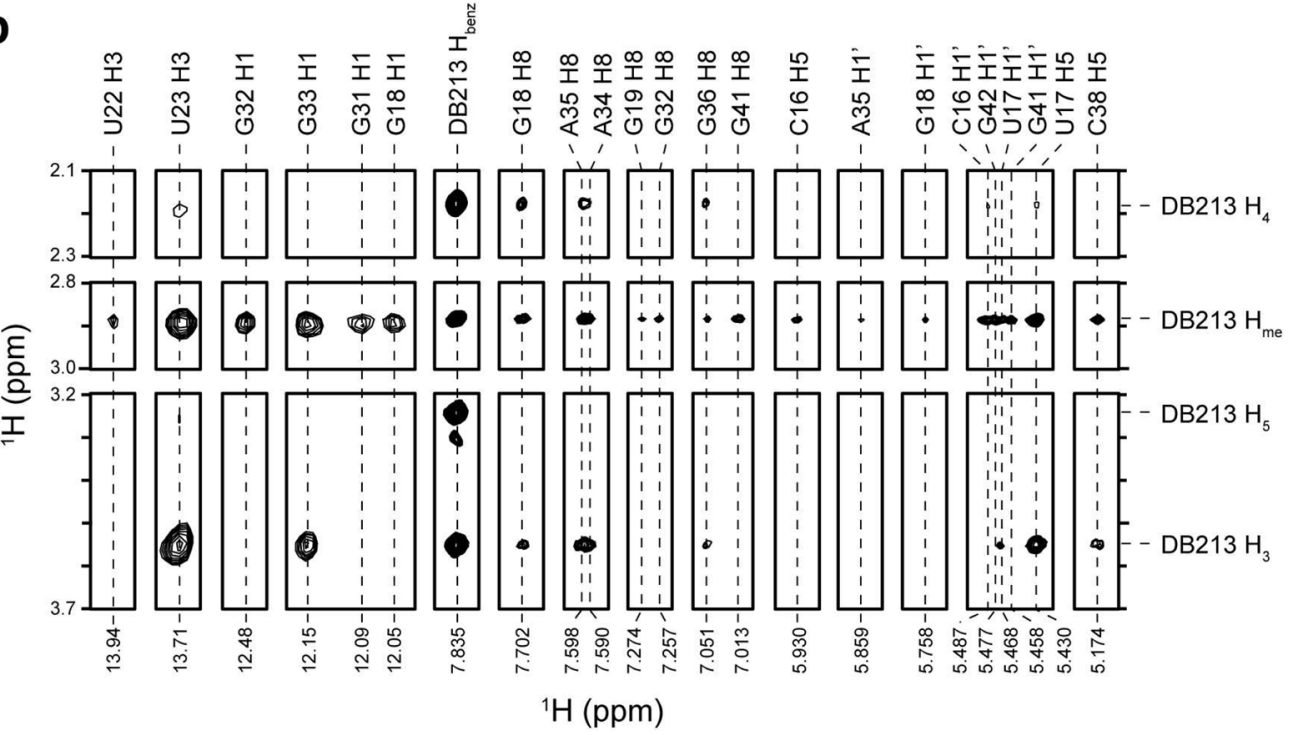

Figure 4.

Localization and apparent affinity of DB213 binding to the HIV-1 FS RNA. (a) Three of seven selected peaks from a 2D ${ }^{13} \mathrm{C}$-TROSY-HSQC-monitored titration of DB213 into the RNA (above). Resonances that display linear changes in ${ }^{1} \mathrm{H}$ and ${ }^{13} \mathrm{C}$ chemical shift indicative of two-state binding behavior (corresponding to nucleotides U15, G42, G43, A44, and A45) were grouped and analyzed by non-linear curve fitting to determine an apparent $K_{d}$ (below). The C16 C5-H5 resonance was omitted from the curve fit owing to apparent non-two state behavior. Error bars indicate the s.e.m. for each data point. (b) Regions of $2 \mathrm{D}^{1} \mathrm{H}-{ }^{1} \mathrm{H}$ NOESY spectra (400 ms mixing time) where NOEs between DB213 and the RNA are observed are shown, and resonance assignments for RNA and DB213 are indicated as numbered in Figure 1, with ambiguous DB213 hydrogen resonances labeled as described in Figure 2. 
a

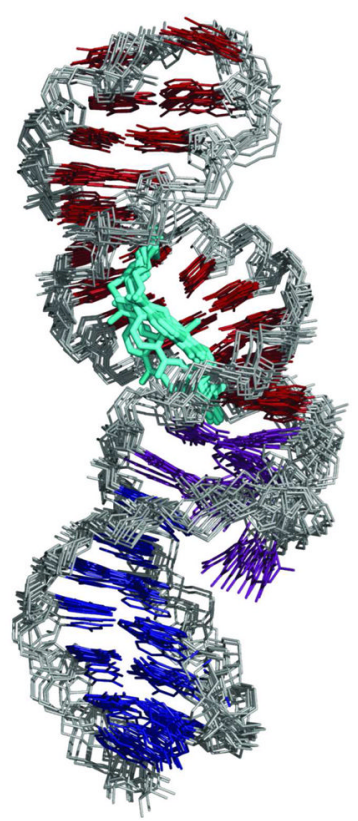

C

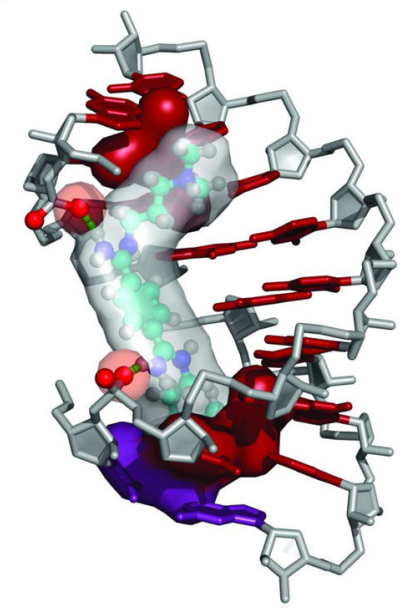

b

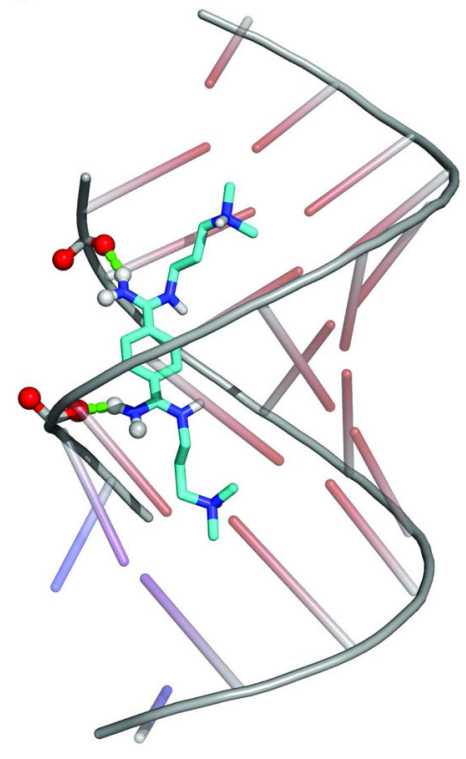

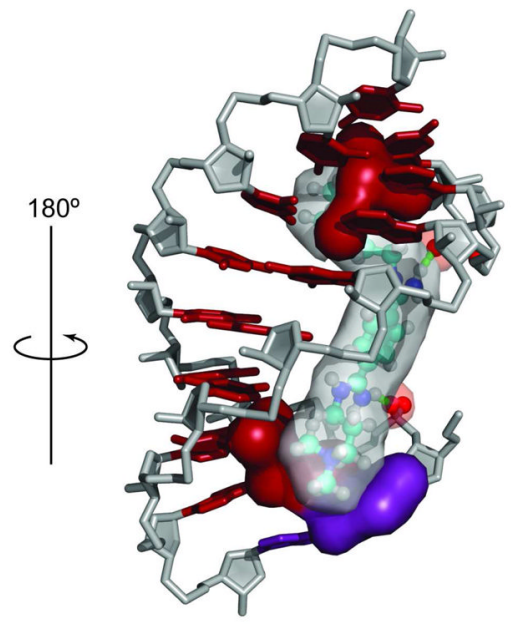

Figure 5.

Structure of the DB213-RNA molecular complex. RNA structural elements are colored as follows: backbone and ribose rings (gray), lower helix bases (blue), upper stem-loop bases (red), GGA bulge bases and flanking base-pairs (violet). (a) Overlay of the 10 lowest energy structures. DB213 is located in the major groove of the RNA, and spans from the $\mathrm{U}_{23}-\mathrm{A}_{34}$ to the $\mathrm{U}_{17}-\mathrm{A}_{40}$ base-pairs. (b) Potential hydrogen-bonds between the amino groups of DB213 and phosphate oxygens on the RNA (green dashed lines connecting red and white spheres). Only solvent-exchangable hydrogens on DB213 are shown and the RNA is shown as a simple ladder model for clarity. One hydrogen bond can be formed between an amino group on DB213 and one of the phosphate oxygens of $\mathrm{A}_{34}$, with an additional bond formed between the other amino group and one of the phosphate oxygens of $U_{17}$. (c) Rotated views of the lowest energy structure indicating van der Waals interactions between DB213 and the RNA (shown as surface representations). Van der Waals contacts are observed between 
DB213 and the following: $\mathrm{C}_{16}(\mathrm{~N} 4, \mathrm{H} 42, \mathrm{C} 4, \mathrm{C} 5), \mathrm{U}_{17}(\mathrm{O} 4, \mathrm{C} 5, \mathrm{H} 5, \mathrm{C} 4), \mathrm{G}_{18} \mathrm{O}$, $\mathrm{G}_{26} \mathrm{O}$, $\mathrm{A}_{34}$ (N7, N6, H61), $\mathrm{A}_{35}$ (N6, H61), $\mathrm{C}_{39}$ (N4, H41), A 40 (N6, H62), and $\mathrm{G}_{41} \mathrm{O}$. 